\title{
Identifying The Needs Analysis of Task-Based Learning Materials
}

\author{
Tri Kusnawati ${ }^{1}$, Yumna Rasyid ${ }^{2}$, Emzir $^{3}$ \\ \{tri.kusnawati@mahasiswa.unj.ac.id ${ }^{1}$, yumna.rasyid@unj.ac.id ${ }^{2}$, emzir.unj@unj.ac.id ${ }^{3}$ \} \\ Universitas Negeri Jakarta, Indonesia ${ }^{1,2,3}$ \\ Universitas Negeri Yogyakarta, Indonesia ${ }^{1}$
}

\begin{abstract}
This article aims to identify the needs analysis of French language learning materials for Indonesian students. This study took place at SMAN 1 Depok Sleman, a public high school that organized the French course. In this article, we tried to justify the need for the identification and analysis of student needs. Needs identification was an ongoing process that occurred before and during learning and was translated into objectives, content, actions, and programs. The tools that we used for data collection included questionnaires, interviews, tests, scales of attitudes, and especially the Common European Framework of Reference for Languages. One of the questionnaires through which we identified the needs of high school students was presented in our communication. These questionnaires were distributed to 32 high school students and one teacher. The questionnaires were hand-delivered. Based on the results of the analysis, we prepared the teaching materials that met the needs of the students.
\end{abstract}

Keywords: needs analysis, learning materials, task-based teaching, and learning.

\section{Introduction}

Students cannot get everything they need to master the French language at a glance. They cannot learn effectively from a collection of exercises and tasks that are random. Thus, the teacher must develop a systematic plan of the learning needs and select and sort the content and the tasks that will guide them to master the French language. A basic assumption is that the development of learning materials should be based on the analysis of the student needs.

A needs assessment is sometimes conducted in response to a deficient situation or one that is felt as such: we then look for what should be the situation correcting the undesirable defective state. But the study of needs can also be considered proactively: in this case, we are looking for what the ideal situation would be. By this progressive approach, we are not aiming at correcting a situation perceived first as deficient, but rather at revealing a need that was not initially felt like a problem, but it becomes a problem once we realize that the current situation can be greatly improved. The first approach is corrective and curative, the second is innovative and visionary.

The satisfactory situation we want to achieve defines the research goals. A person or group's awareness of the significant gap between the current unsatisfactory situation and the desired situation defines the needs to be met by reducing these deficiencies. Educational needs are above all perceived deficiencies between actual results, consequences or achievements of teaching-learning and those that are desired. 
Learning materials can be developed for a variety of reasons. They can, and often do, respond to a need identified by a teacher in a class for all students or only a part of them. They can be a way for a teacher to diversify teaching methods. Finally, they can be the result of a passion in a given field that has materialized in the production of learning materials.

Needs Analysis is a procedure used to gather information about the needs of students. According to [1] needs analysis have various purposes in language learning: (1) to know the language skills that students need to be able to play a specific role, such as sales managers, tour guides, doctors, etc., (2) to help for determining if language learning is potentially geared to the needs of students, (3) to determine which students in the group most need specific language skills training, (4) to identify changes to the most important language learning objectives for students, (5) to identify the gap between what students can do with what they need, and (6) to gather information about student-specific issues based on their experiences.

Analyzing needs means trying to identify needs by interviewing various actors and it is also a way of analyzing one's practices. Thus, some problems can be raised as part of the needs analysis that will need more time to be clarified. If the learning material is to be widely used, the needs analysis is the prerequisite for any development of the teaching methods.

The needs analysis leads to the conclusions that it will be included in the estimate of the learning material since it is partly this analysis that justifies the realization of the product. The practices and processes that can be used to conduct a needs analysis are extremely diverse.

A needs analysis can cover:

a. A simple census of applications to teachers, for example. Their demands may be more or less spontaneous or influenced by an open or closed policy on education.

b. A detailed survey carried out with the assistance of all the stakeholders involved in the college network, namely the management, the directors of teaching programs, the teachers. At some point, opinions from the students themselves can be gathered.

\section{Procedures}

On a strict methodological level, we can describe the needs analysis process in five sentences:

a. The target audience: This is to determine with precision the public concerned. It may be necessary to discern several types of public, a certain heterogeneity or, on the contrary, common characteristics such as age, level of education, living conditions, socioprofessional environment, etc.

b. The observation: It is a question of obtaining a representation as precise as possible of the situation in which the chosen public is interested in (what goes, what is wrong).

c. The problem: It completes the observation by presenting hypotheses explaining the situation, risking a diagnosis.

d. The intended learning material (as described in the project call).

e. The action plan: What decision will be taken for the realization of the project? Does a product meeting the objectives and which would avoid embarking on an expensive 
development not exist already on the market? If there is a product in another language, is it not possible to translate and adapt it? Is the proposed solution (learning material) feasible?

The tools for collecting the information include the best-known ones that are available to the interested parties: questionnaires, interviews, target setting, language tests, attitude scales, surveys, and especially the Common European Framework of Reference for Languages [2], which offers the means of elaboration of the questionnaires of identification of needs. It describes all the language skills and knowledge required to develop them. Furthermore, instead of the three levels of traditional knowledge (basic, intermediate, and advanced), it restores a scale of six reference levels based "on the current practice of a number of public certification bodies".

\section{Methodology}

The subject of this research is represented by the pupils of the XIIth year of social studies enrolled in the high school of SMAN 1 Depok Sleman in the academic year 2017/2018. The total number of students was 25. The instrument of research is questionnaires. Data were collected in July 2017. The technique of analyzing data is the descriptive analysis.

\section{Result and Discussion}

\subsection{The Problems}

In this category, we asked the students to identify the problems encountered by themselves and the teacher when learning the French language in the classroom.

Table 1. the Easiest to Most difficult Skill for Studying French

\begin{tabular}{cc}
\hline Speaking & $21.8 \%$ \\
\hline Grammar & $21.6 \%$ \\
\hline Listening & 17.3 \\
\hline Vocabulary & $15 \%$ \\
\hline Reading & 13.6 \\
\hline Writing & $10.5 \%$ \\
\hline
\end{tabular}

The results show that among high school students, the easiest skill to teach students is speaking $(21.8 \%)$; followed by the French grammar $(21.6 \%)$, the listening comprehension $(17.3 \%)$, the vocabulary $(15 \%)$, and reading comprehension $(13.6 \%)$. According to the students, the most difficult skill is writing $(10.5 \%)$. 


\subsection{Priorities}

In this category, students were asked to investigate the subject, language skills, and others that are important for them to learn.

Table 2. The Most Used Skill for Studying French

\begin{tabular}{cc}
\hline Grammar & $23 \%$ \\
\hline Speaking & $19 \%$ \\
\hline Vocabulary & $17.5 \%$ \\
\hline Listening & $16.2 \%$ \\
\hline Reading & $13.5 \%$ \\
\hline Writing & $10.7 \%$ \\
\hline
\end{tabular}

According to the responses, the skills that are most frequently used by students in learning French are French grammar; while the rarest skills used is the writing skill.

Table 3. The Most Necessary Learning Material

\begin{tabular}{cl}
\hline Listening & $\begin{array}{l}\text { Listening French } \\
\text { pronunciation and intonation }\end{array}$ \\
\hline Speaking & $\begin{array}{l}\text { How to pronounce words and } \\
\text { phrases in French }\end{array}$ \\
\hline Reading & To read the text to be able \\
& to understand the main \\
& ideas and detailed idea \\
& accurately \\
& To read the text to be able \\
& to understand difficult \\
& words and special \\
& terminology \\
\hline Writing & Writing positive and negative \\
& phrases \\
\hline
\end{tabular}

The most necessary learning material for learners for the listening comprehension skill is the Listening French pronunciation and intonation, for speaking is how to pronounce words and phrases in French, for the written comprehension skills is to read the text to be able to understand the main ideas and the detailed ones accurately and to read the text to be able to understand difficult words and special terminology, and for the written production skill is to write positive and negative phrases. 


\subsection{The Types of Tasks Needed in French Teaching Materials}

In this category, we asked students to identify types of tasks needed in French teaching materials. Based on their responses, we showed that students need all types of tasks in the teaching materials.

\section{Conclusion}

The study results showed us that students hope to learn French by using materials that meet their needs.

All those involved in the learning process, namely, the institution, teachers, and learners, know that identifying needs is not a momentary or one-way process. It can be done before or even during the apprenticeship. Identifying needs before learning ensures awareness of the resources we have and the goals we want to achieve. However, sometimes the learner's needs change more or less during his training. In this case, a new identification of the needs will make the teacher or institution to consider this change and modify the resources accordingly.

\section{Acknowledgments}

The author would like to thank the Minister of Research and Technology and Higher Education for awarding scholarships for doctoral programs. The author also would like to thank the Rector of Yogyakarta State University for authorizing the author to study and Prof. Dr. Yumna Rasyid, M.Pd. and Prof. Dr. Emzir who guided him in conducting this research.

\section{References}

[1] Conseil de 1'Europe: Cadre Européen Commun de Référence pour les Langues. pp. 5. Didier, Paris (2000).

[2] McGrath, I.: Material Evaluation and Design for Language Teaching. Edinburg University Press, Edinburg (2002).

[3] Graves, K.: Designing Language Courses: A Guide for Teacher. Heinle and Heinle Thomson Learning, Boston (2000).

[4] Nunan, D.: Design Task for the Communication Classroom. p. 59-61. Cambridge University Press Cambridge:, (2004).

[5] Richards, J. C.: Curriculum Development in Language Teaching. pp. 26-52. Cambridge University Press, Cambridge (2005).

[6] Richterich, R. et Chancerel, J.: L'Identification des Besoins des Adultes Apprenant une Langue Étrangère. Conseil de l'Europe, Projet Langues Vivantes. Hatier, Paris (1997).

[7] Tagliante, C.: Techniques de Classe: La Classe de Langue. Clé International, Paris (1994).

[8] Tomlinson, B. (ed).: Developping Materials for Language Teaching. Continuum, London (2007). 